Abstracta Iranica Abstracta Iranica

Revue bibliographique pour le domaine irano-aryen

Volume 42-43 | 2021

Comptes rendus des publications de 2019-2020

\title{
Forogh Hashabeiky (éd.). Tavlan: En antologi med persiska noveller skrivna efter revolutionen i Iran 1979
}

\section{Bernard Christophe}

\section{(2) OpenEdition \\ 1 Journals}

\section{Electronic version}

URL: https://journals.openedition.org/abstractairanica/54372

DOI: 10.4000/abstractairanica.54372

ISSN: 1961-960X

Publisher:

CNRS (UMR 7528 Mondes iraniens et indiens), Éditions de l'IFRI

\section{Electronic reference}

Bernard Christophe, "Forogh Hashabeiky (éd.). Tavlan: En antologi med persiska noveller skrivna efter revolutionen i Iran 1979", Abstracta Iranica [Online], Volume 42-43 | 2021, document 3, Online since 30 December 2021, connection on 14 December 2022. URL: http://journals.openedition.org/ abstractairanica/54372 ; DOI: https://doi.org/10.4000/abstractairanica.54372

This text was automatically generated on 14 December 2022.

All rights reserved 


\title{
Forogh Hashabeiky (éd.). Tavlan: En antologi med persiska noveller skrivna efter revolutionen i Iran 1979
}

\author{
Bernard Christophe
}

\section{REFERENCES}

Forogh Hashabeiky (éd.). Tavlan: En antologi med persiska noveller skrivna efter revolutionen i Iran 1979. Uppsala: Uppsala Universitet, 2020, 206 p. (Studia Iranica Upsaliensia 37), (Open Access)

Tavlan is a collection of thirteen Persian short stories in Swedish translation. The stories were all written after the Islamic Revolution of 1979 and originally published both in Iran and in some other countries where there is a Persian-speaking diaspora. The title of the collection should probably remind the reader of the diversity of the "treats" offered in this collection. According to the editor, one of the criteria orienting the choice of pieces to be included was to offer the reader as much as possible a differentiated panorama of contemporary Persian prose, with respect to subject matter, narrative style and, to a minor extent, place of publication. Moreover, the editor avoided including pieces that have been previously published in Sweden, thus giving the public the opportunity of becoming acquainted with internationally lesserknown authors. Some of their works have probably never been published in translation before, even though several authors have won prestigious literary prizes, as can be learned from the short biographies of the authors included in the end of the volume (Författarpresentationer). There is also a short biographical section about the translators of the stories, whose importance for this collection cannot be overestimated. The bibliography section indicates several other anthologies of Persian literature in both Swedish and English, some of which are also described in the introductory chapter. These indications would be of particular interest for students of Persian literature. 
2 The book includes a background section (Bakgrund), in which a short sketch of the history of Persian literature is presented. While this section might serve as a very first approach to the subject for neophytes in the field, serious students would most probably have to rely on more comprehensive accounts, as parts of this presentation are indeed rather sketchy.

3 Among the stories included in the collection is "You whose homeland is not here" (Du vars hemland inte är här) which depicts very vividly the conditions of life of an Afghan refugee struggling for survival in Teheran. This impressive story should be made compulsory reading for all those who, leading comfortable lives in Europe, ask why Afghan refugees cannot seek protection in their own region. "The spindle" (Spindeln) is also set in Teheran, but here the "heroes" are a middle-class couple struggling with marital problems and trying to cope with the conflict between modernity and traditional norms. Two of the stories - "Hell" (Hålan) and "I am [your] son's murderer" (Jag är sons mördare) are set during the time of the war between Iran and Iraq; the second one is written as a letter to the father of a fallen soldier by the one who was forced to kill him in order to save other soldiers' lives. "Mr. Davoud's trivial thoughts" (Herr Davouds triviala tankar) depicts the life of a middle-aged Iranian man in German exile. "The Buddha at the Whirlwind Restaurant" (Buddhan pa restaurang Virvelvinden) is a rather funny philosophical monologue about a man's quest for truth. "The Road" (Landsvägen) discusses in an introspective way the problems of an aged woman in rural Iran. All the stories are shortly summarized in the introductory chapter. A small number of footnotes provide explanations about specific aspects probably unfamiliar to most Swedish-speaking readers. Characteristic for all stories is, in my opinion, a straightforward language that enables the reader to relate easily to the narratives.

It has often been said that literature is a way of gaining experience otherwise inaccessible to the reader. This certainly applies to the present collection. The issues raised are relevant not only in order to understand conditions in present-day Iran, but also to gain an insight into essentially universal problems in a completely different setting. For the benefit of students wishing to advance in their studies, a companion volume with the original texts, a glossary and more detailed notes should be published.

\section{AUTHORS}

\section{BERNARD CHRISTOPHE}

Université de Halle 